\title{
Could the grasses have played a role in the earliest salt exploitation? Phytoliths analysis of prehistoric salt spring from Hălăbutoaia - Țolici (Romania)
}

\author{
Mihaela Danu $^{1}$ (D) Claire Delhon ${ }^{2} \cdot$ Olivier Weller $^{3}$ \\ Received: 3 July 2020 / Accepted: 18 October 2020 / Published online: 31 October 2020 \\ (C) The Author(s) 2020
}

\begin{abstract}
The salt spring exploitation from Hălăbutoaia - Țolici (Neamț County, Romania) dates back to the Early Neolithic and lasted throughout Chalcolithic. The deposit stratigraphy is estimated at $8 \mathrm{~m}$ and covers 2500 years of history (c. 6000-3500 BCE). In order to document the possible use of plants, particularly of the grasses, in the salt production process, we realized a detailed study of phytoliths preserved in several archaeological levels of Hălăbutoaia site. The most identified morphotypes come from grass family. Analysis revealed an important representation of inflorescence bracts phytoliths (especially ELONGATE DENDRITIC) showing the anthropogenic origin of the assemblages. BILOBATE are also well represented. These forms attest the presence of wild panicoid grasses (e.g. wild millet) and/or cultivated millets in the area. In some very punctual assemblages, forms produced by dicots are well represented. Considering the low phytoliths production by dicots plants, it involves a special accumulation of these types of plants that could be related to woody plants used as fuel for salt production. It is very possible that grasses had a very important role in pyrotechnology used to produce salt, either as the main fuel or as a mean for controlling the temperature or even as a firelighter.
\end{abstract}

Keywords Salt spring $\cdot$ Neolithic $\cdot$ Cucuteni $\cdot$ Criş culture $\cdot$ Phytoliths $\cdot$ Romania

\section{Introduction}

The sub-Carpathian area from Eastern Romania is characterized by a high density of saltwater springs: over 200 are

Supplementary Information The online version contains supplementary material available at https://doi.org/10.1007/s12520-02001228-6.

Mihaela Danu

danum2007@yahoo.com

Claire Delhon

claire.delhon@cepam.cnrs.fr

Olivier Weller

olivier.weller@cnrs.fr

1 Department of Biology, Faculty of Biology, Alexandru Ioan Cuza University of Iaşi, Romania, Carol I Bvd., No. 20A, 700506 Iași, Romania

2 CNRS, CEPAM, UMR 7264, Université Côte d'Azur, Nice, France

3 CNRS, Trajectoires, UMR 8215, Université Paris 1 Panthéon-Sorbonne, Paris, France registered (Alexianu et al. 2007; Weller and Brigand 2017). The exploitation of some of these dates back from the Early Neolithic, during the Criş culture (Weller and Dumitroaia 2005), and represents one of the earliest evidences of salt production in Europe. Moreover, contrarily to other prehistoric salt springs in Europe (such as those from Germany or France), those from Eastern Romania have been constantly exploited through time, and the natural brine is still used by locals nowadays (Alexianu et al. 1992, 2007). The Hălăbutoaia - Țolici (Petricani, Neamț County) saltwater spring, discovered in 2005 (Weller et al. 2007) and highly concentrated in sodium chloride, presents direct and very accurate evidence of salt exploitation during the Neolithic and Chalcolithic periods (Brigand and Weller 2013, 2018; Dumitroaia 1994; Weller and Brigand 2017; Weller and Dumitroaia 2005; Weller et al. 2007, 2015). Its excavation revealed that it was probably a seasonal salt exploitation point (Dumitroaia et al. 2008; Monah 2008), extensively used throughout the Neo-Eneolithic (Weller et al. 2015). Seasonal or not, it is certain that natural brine and salt production was an important aspect of prehistoric activities in this area. Two techniques seem to have been practiced: pouring natural brine 
onto combustion structures during the Early Neolithic and evaporation in specific ceramic containers from the Chalcolithic onwards (Sordoillet et al. 2018).

The whole salt extraction process involves the exploitation not only of the brine itself but also of several other natural resources, of which a major one is fuel. In order to elucidate some traits of the prehistoric salt production process, several analyses were run on two Early Neolithic salt working sites: Poiana Slatinei in Lunca (Neamț County) by archaebotany and micromorphology (Dufraisse et al. 2010; Weller et al. 2008) and Hălăbutoaia near Țolici by palynology (Danu et al. 2010), micromorphology and SEM-EDS analysis (Sordoillet et al. 2018).

In order to better document the use of plants in the salt production process, in particular for the heating of the saltwater and the management of vegetal resources, we carried out a detailed study of phytoliths from the levels linked with salt extraction at Hălăbutoaia site. These microremains were very well-preserved in several archaeological levels assigned from Criș to Cucuteni Cultures (c. 6000-3500 BCE). The underlying issues concerned the influence of the environment on the salt extraction process and more specifically the impact of the local vegetation on the salt extraction techniques. As they are a link of the operational chain, the availability of the plants used as fuel may have influenced the whole process, and it may be one of the reasons why this activity could have been seasonal. Moreover, the recourse to phytolith analysis allows tracing non-wood plants, which are often underestimated when the question of fuel is considered.

Phytoliths, amorphous silica $\left(\mathrm{SiO}_{2}\right)$ bodies which are formed both within and between the living plant cells (Currie and Perry 2007; Madella and Lancelotti 2012; Piperno 1988), may provide important data for palaeoenvironmental reconstruction (Borba-Roschel et al. 2006; Carter and Lian 2000; Rovner 1971), and they can be successfully used in palaeoecology (Fredlund and Tieszen 1997; Li et al. 2017; Lu et al. 2007; Murungi et al. 2017; Piperno 1989) and archaeology (Albert et al. 1999; Delhon et al. 2008; Messager et al. 2011; Ollendorf 1987; Piperno 1988). Due to the physico-chemical properties of opal, these bio-indicators are preserved very well in many sedimentary contexts, being undoubtedly the most sustainable plant fossils known so far (Piperno 2001). Although their taxonomic value is generally inferior to other botanical indicators, the phytoliths analysis presents the huge advantage that these proxies allow the determination of grass subfamilies (which is impossible with fossil pollen). Their use in archaeological context becomes more important as the signal given by these indicators is local: phytoliths are released into sediments or soil and are considered to be mainly the subject of an in situ deposition, as aerial dispersion is most of the times nearly absent, contrarily to what happens with pollen (Lebreton et al. 2017). Phytoliths dispersal can be influenced by strong winds, but their in situ deposition, which is aided by gravity, remains dominant (An et al. 2015; Garnier et al. 2012; Piperno 2006).

We also tried to correlate the information obtained from phytoliths analysis with palynological research results (Danu et al. 2010), as well as other archaeobotanical data (Dufraisse 2011), in order to interpret it taking into account the ancient environmental conditions from Hălăbutoaia - Țolici. Phytoliths found at the site are derived from the palaeoenvironment, although they reflect only specific part of it because the phytolith assemblages results from anthropic activities.

\section{The Hălăbutoaia - Țolici site and its setting}

Situated to the East of the Eastern Carpathians, in the contact area between Moldova Valley and the Neamț Subcarpathian Depression, the Târpești - Țolici - Petricani micro-region is rich in saltwater springs, one of them being Hălăbutoaia Țolici. Except for a few archaeological surveys, the exploitation of salt in this micro-region received little attention and was therefore poorly understood. Regarding archaeological science, only a few ancient palaeoecological studies have been carried out at the Neolithic settlement of Râpa lui Bodai in Târpești, located $6 \mathrm{~km}$ north of the salt spring (MarinescuBîlcu et al. 1981). Discovered during our archaeological survey in 2005 (Weller et al. 2007) and then excavated in 20072010 (Weller et al. 2015), the Hălăbutoaia - Țolici salt spring is situated in a relatively narrow and deep valley, in the southwest of Țolici village, Petricani, Neamț County (Fig. 1).

The main archaeological deposit is at the base of the east slope of Hălăbutoaia hill, $40 \mathrm{~m}$ away from a saltwater well. The anthropic deposit has the form of an ovoid mound with diameters of approximatively $30 \times 20 \mathrm{~m}$; the general slope and the south side of the deposit are affected by an advanced erosion process revealing large quantities of fragmentary ceramics. Through a large trench in the middle part (SI, $15.5 \times$ $1.5 \mathrm{~m}$ ), this salt working site occurs as thick archaeological sedimentary accumulations, which are several metres high and comprise numerous lenticular layers of clay, ash and charcoal (Fig. 2).

The Neo-Eneolithic deposits represent a 8-m accumulation of combustion features and ceramics, with $1.30 \mathrm{~m}$ below the actual stream Pârâul Slatina. The whole sequence indicates the exploitation of the salt spring with typical combustion features and specific ceramic moulds usually known as briquetage (Weller 2015). At this salt workshop, only an artificial evaporation process would have been used in order to concentrate, until crystallization was reached, the natural highly concentrated saltwater spring using fire (ignigenous salt).

The trench allowed the study of the 7-m-thick visible stratified accumulation. The main litho-stratigraphic characteristics 


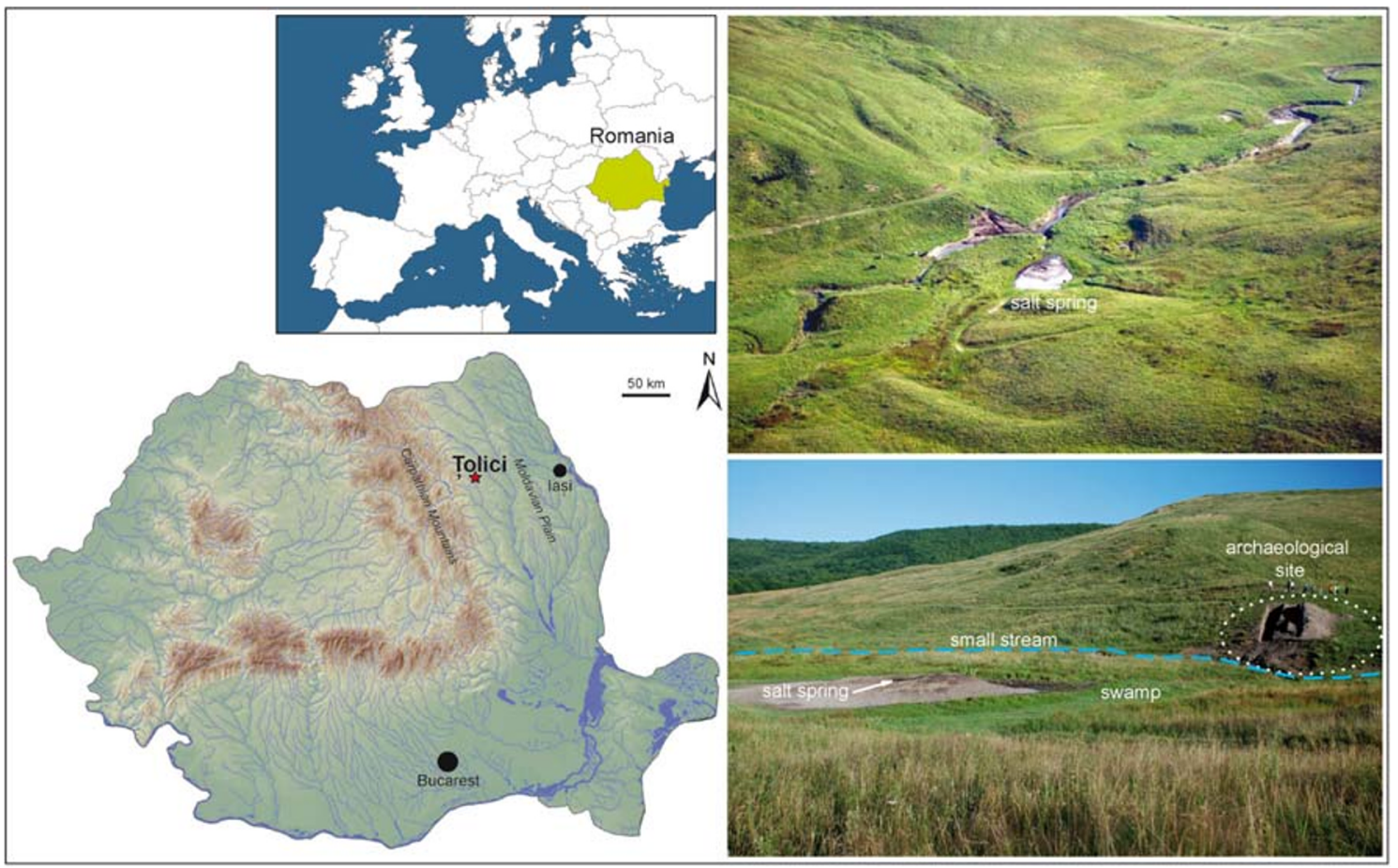

Fig. 1 Location of the archaeological site Hălăbutoaia at Țolici (Petricani, Neamț). Aerial photography with the salt spring in the middle (above); extension of the archaeological deposit indicated by white dotted ellipse (bottom). Map: R. Brigand \& O. Weller; Photos O. Weller

of the 29 recorded strata (from A to Z4) reveal abundant combustion structures, as shown by the superposition of ashy- charcoal residues on reddened clay (Sordoillet et al. 2018). Radiocarbon dating (Table 1) and abundant typical ceramic

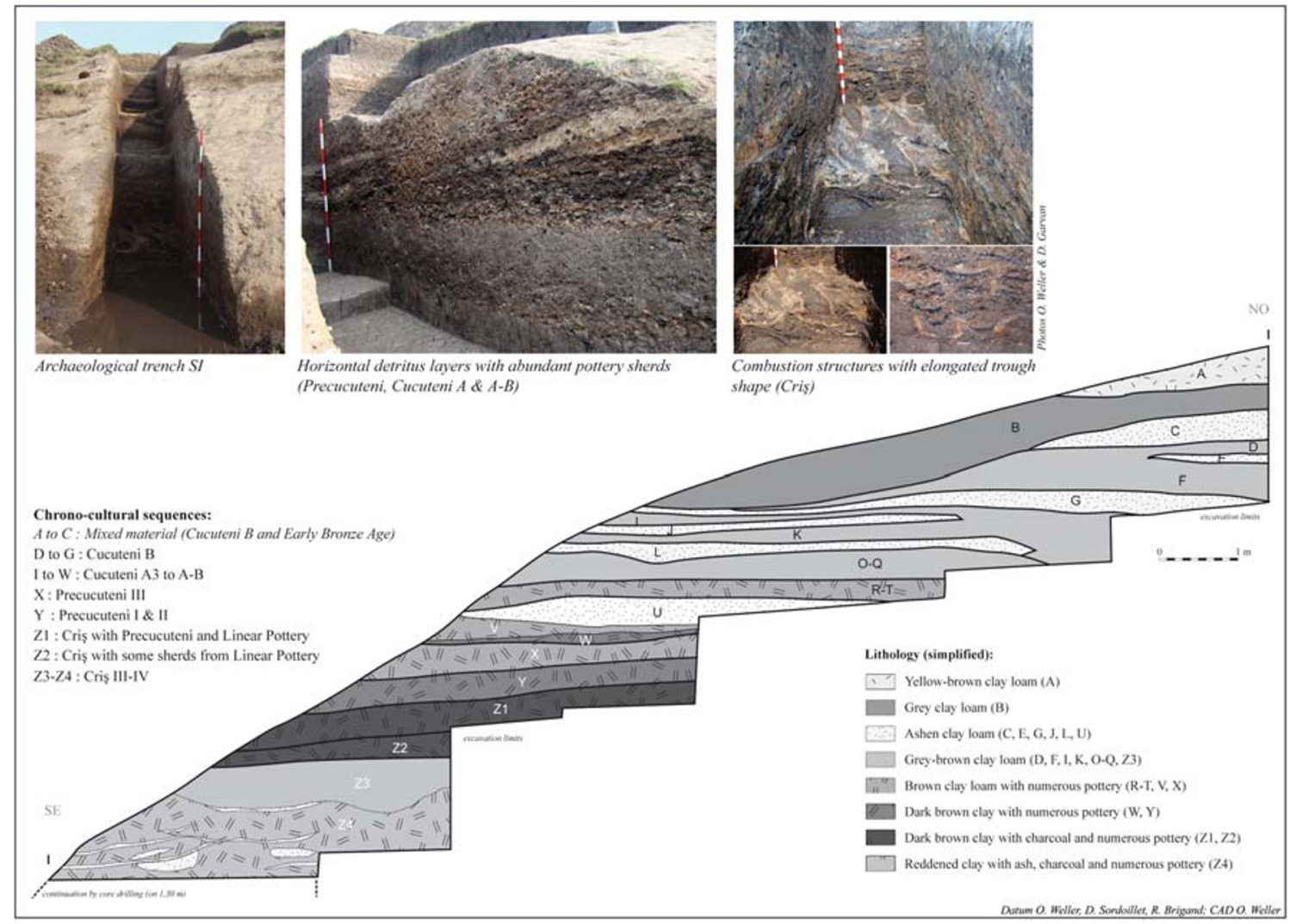

Fig. 2 Archaeological deposit and section at Hălăbutoaia - Țolici (SI) 
Table 1 Radiocarbon dates from Hălăbutoaia - Țolici

\begin{tabular}{lllll}
\hline $\begin{array}{l}\text { Stratigraphic unit (section SI) } \\
\text { and core depth }(\mathrm{cm})\end{array}$ & Laboratory ID & Material & ${ }^{14}$ C age (BP) & $\begin{array}{l}\text { Calibrated age (BC) } \\
95.4 \% \text { probability }\end{array}$ \\
\hline SI (C-D) & Poz-30826 & Charcoal & $4660 \pm 35$ & $3620-3600 ; 3530-3360$ \\
SI (O) & Poz-30828 & Charcoal & $5320 \pm 40$ & $4320-4290 ; 4270-4040$ \\
SI (U) & Poz-30829 & Charcoal & $5300 \pm 40$ & $4260-3990$ \\
SI (V) & Poz-18749 & Charcoal & $5520 \pm 40$ & $4460-4320 ; 4290-4270$ \\
SI (W) & Poz-30830 & Charcoal & $5480 \pm 40$ & $4450-4410 ; 4400-4240$ \\
SI (W-FA4) & Poz-18753 & Charcoal & $5650 \pm 40$ & $4560-4360$ \\
SI (Z3) & Poz-41438 & Charcoal & $6280 \pm 40$ & $5360-5207 ; 5162-5138 ;$ \\
& & & & $5129-5120 ; 5094-5080$ \\
SI (Z4) & Poz-18751 & Charcoal & $6630 \pm 50$ & $5630-5480$ \\
SI (Z4) & Poz-18752 & Charcoal & $6660 \pm 40$ & $5660-5510$ \\
$35(Z 4)$ & Poz-18754 & Charcoal & $6750 \pm 40$ & $5730-5610 ; 5590-5570$ \\
$70(Z 4)$ & Poz-24385 & Charcoal & $6760 \pm 40$ & $5730-5610$ \\
$152(Z 4)$ & Poz-24424 & Charcoal & $6840 \pm 50$ & $5840-5630$ \\
\hline
\end{tabular}

material place the beginning of exploitation at around $5700 \mathrm{BCE}$ and the end toward 3500 BCE. The wellpreserved combustion structures with an elongated trough shape characterize the Early Neolithic exploitation (Criş culture), whereas the horizontal detritus layers with abundant pottery sherds characterize the Chalcolithic ones (Precucuteni and Cucuteni cultures). This remarkable deposit seems to illustrate almost all cultures and chronological stages known in Moldova, starting with Criș and until the end of the Cucuteni culture with Early Bronze Age elements, which makes this site exceptional (Dumitroaia et al. 2008; Weller et al. 2015).

\section{Material and method}

Twenty-six samples from several stratigraphic units (US) were collected for phytolith analysis (Fig. 3; Supplementary material 1, available online). For each US (or combustion structure, all described in Sordoillet et al. 2018 - appendix B), the samples were homogeneous and grouped (see Fig. 3 ), the maximum distance between the samples being $12 \mathrm{~m}$. Seventeen samples were directly obtained from micromorphological blocks, which insured a twofold interpretation and allowed to consider diverse stratigraphic contexts (mostly ash features with hearths, but also secondary deposits with maintenance and waste). The chronological distribution is as follows: 8 for the Early Neolithic deposits (Criș cultural period), 1 for the Final Neolithic/Early Chalcolithic (Precucuteni) and 17 for the Chalcolithic (Cucuteni, with 11 for Cucuteni A and A-B, and 6 for Cucuteni B).

Phytoliths extraction was carried out in UMR 7264 CEPAM Université Côte d'Azur - CNRS, starting from a sample of sediment of between 1 and $3 \mathrm{~g}$. For chemical preparation, we followed the standard protocol of the laboratory:
- Clay deflocculation with distilled water under magnetic stirring, $200 \mu \mathrm{m}$ tumbling for coarse particles removal, centrifugation $2000 \mathrm{t}$. $\min ^{-1}$ for clay elimination

- Decarbonation with concentrated hydrochloric acid (33\%) by heat and using the ultrasonic bath

- Organic matter oxidation under hot and ultrasonic action: $\mathrm{KOH}(10 \%)$, nitric acid $(30 \%)$ and hydrogen peroxide $(30 \%)$

- Phytoliths densimetric separation with sodium polytungstate, density $=2.35$

Then, the rinsed and dry extract was poured into ethanol, after which few drops were fixed on a microscopic slide using immersion oil. Observation was made at optical transmission microscope, with magnification from $\times 400$ to $\times 1000$. For each sample, at least 200 phytoliths with an identified morphology were counted. Phytoliths were named following the International Code for Phytolith Nomenclature 2.0 (ICPT 2019).

\section{Results and discussion}

The samples from T,olici were found to be rich in phytoliths, except for few ones: Tol08.11, where phytoliths were less concentrated; Tol08.1 and Tol10.7 in which low concentration of phytoliths did not allow analysis to be done (although two extraction tests were performed for the first one); and Tol10.12 in which no phytoliths were observed.

\section{Identified morphotypes}

In this study, 13 morphotypes have been distinguished: RONDEL, Bilobate, Crenate, Saddle, Papillate, Elongate dendritic, Elongate entire, Elongate sinuate, Acute bulbosus, 


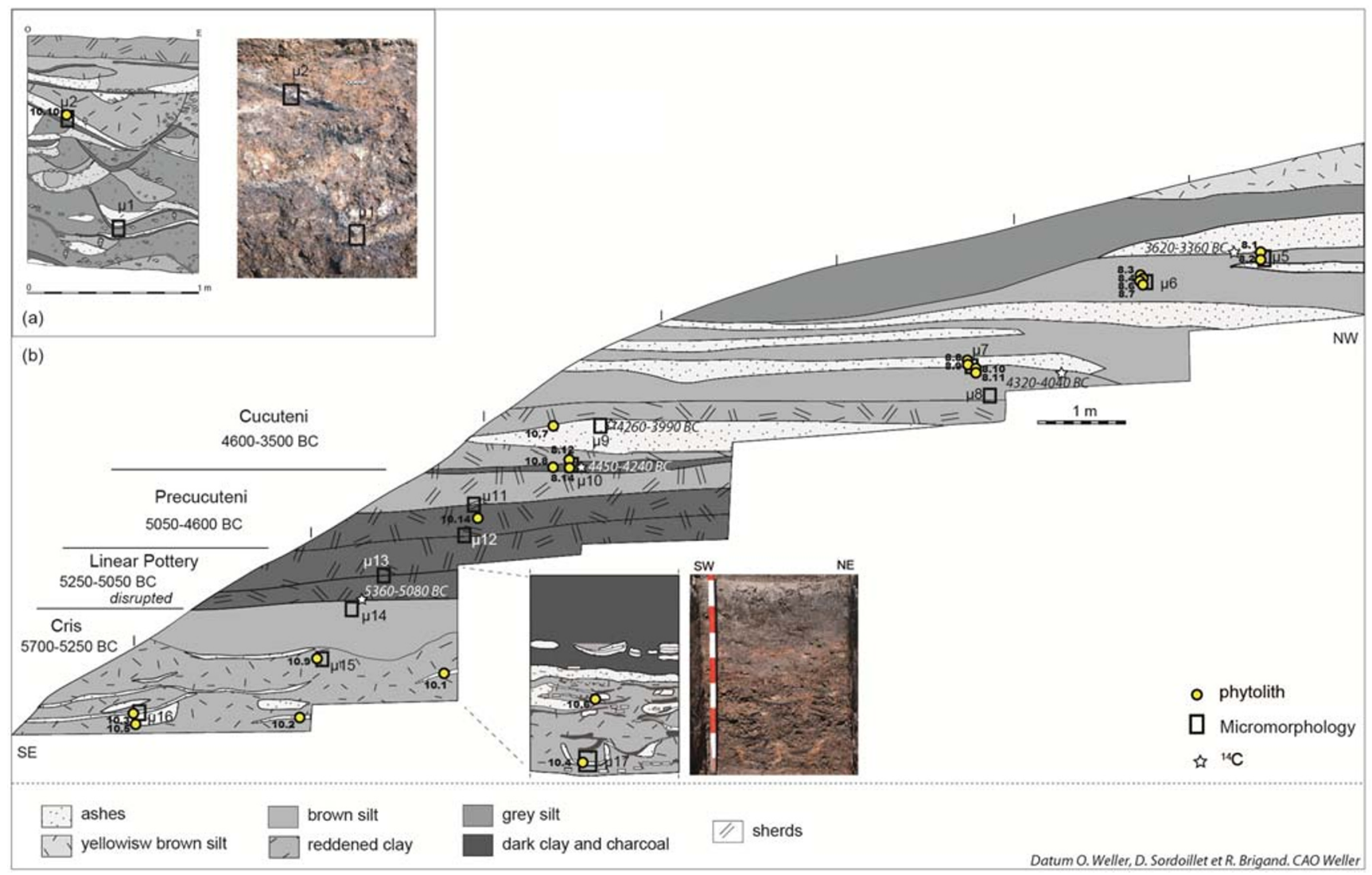

Fig. 3 Stratigraphic section, radiocarbon dating and sampling. (a) First samples from the elongated hollow at the base of the archaeological mound at Țolici, when it was discovered; (b) Sampling from the different chronological levels of the main stratigraphic section (SI, profil SW)

Spheroid, Bulliform flabellate and Blocky, including Phragmites-type, tabular polygonal Cyperaceae-type and
TRACHEARY (Fig. 4, Table 2). Articulated phytoliths, also known as silica skeleton, were observed.
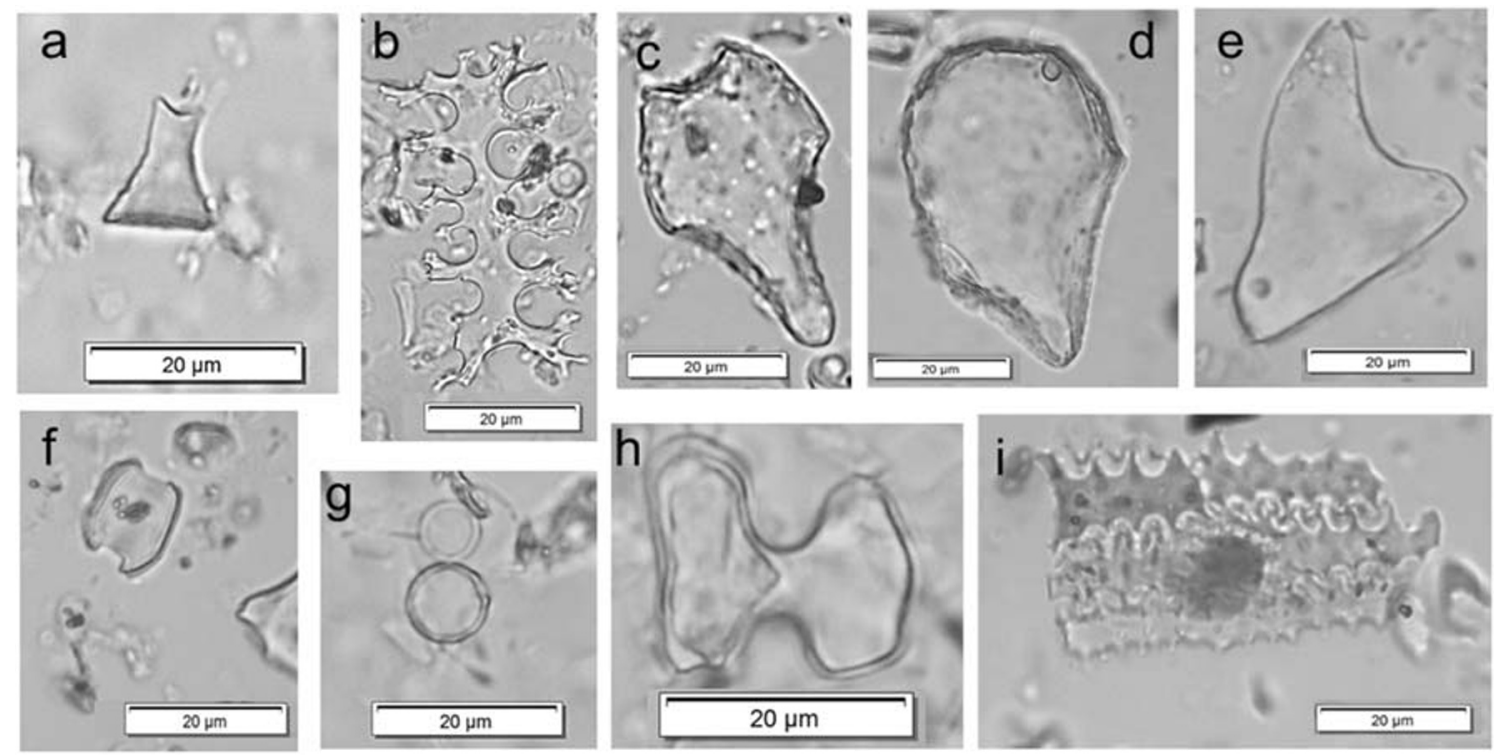

Fig. 4 Examples of phytolith morphotypes identified in Hălăbutoaia T,olici samples: a Rondel, b Elongate Dendritic, c Bulliform flabellate, d Bulliform flabellate (Phragmites-type), e Acute
Bulbosus, f Saddle, g Globular, psilate, h Bilobate and i silica skeleton made of several ELONGATE DENDRITIC 


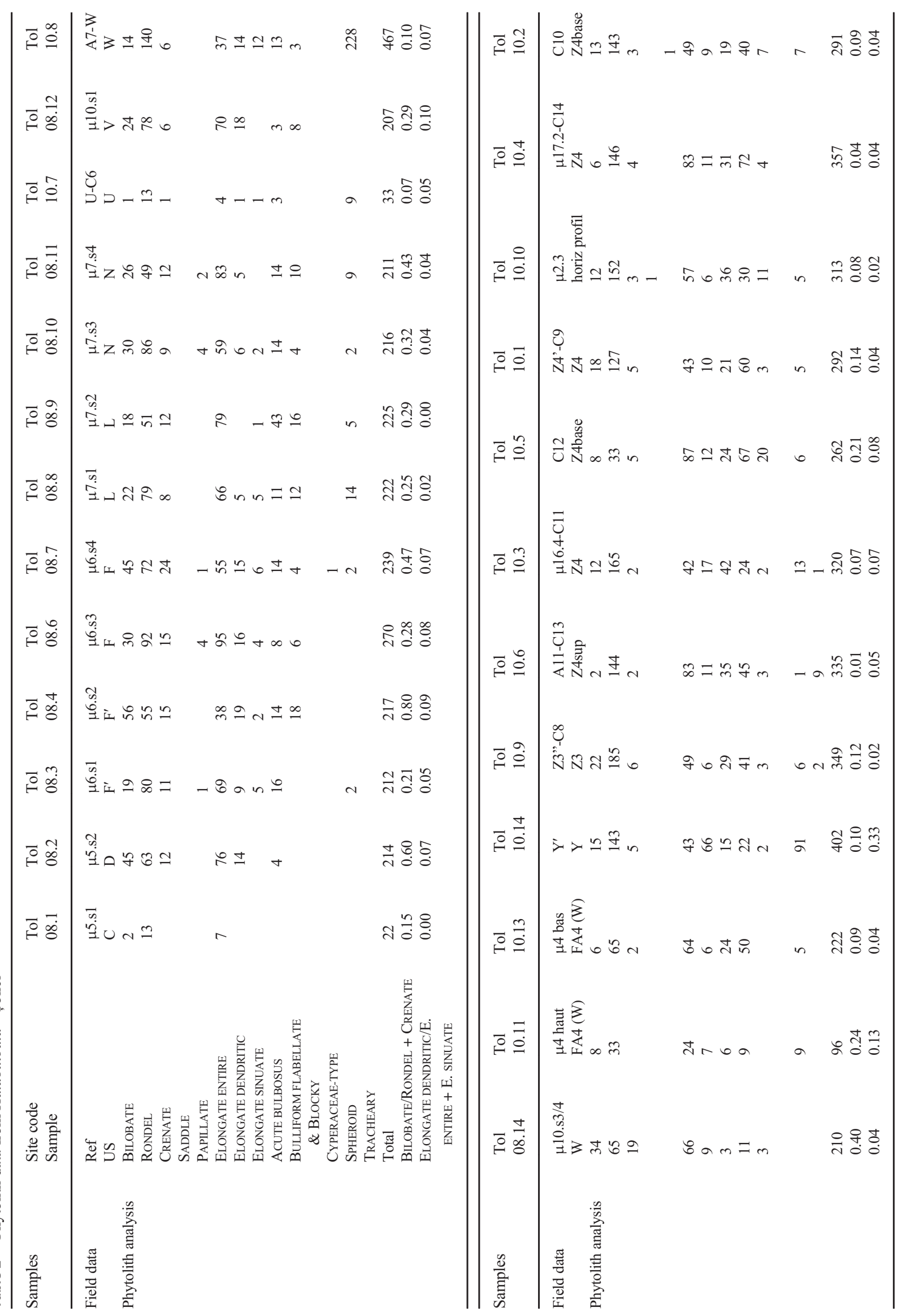


Most of identified morphotypes are assigned to grasses. A characteristic feature of Cyperaceae family has been identified only once, but it should be emphasized that this morphotype is considered fragile and it could be affected by low preservation (Borba-Roschel et al. 2006). Also, rarely and only in certain levels, SPHEROID, which are considered as characteristic of the dicotyledonous plants (Albert et al. 1999; Alexandre et al. 1997; Bozarth 1992; Delhon et al. 2003; Runge 1999), were registered. These forms do not allow a more accurate identification. Despite being often attributed to dicots, TRACHEARY phytoliths have an uncertain origin (primary, secondary, xylem or phloem?), and it seems that they could be produced by a wide range of plants (ICPT 2019).

Among the grass silica short-cell phytoliths, several morphological features can be distinguished. The main type of silica short cell varies between the grass subfamilies (Rovner 1971, Twiss et al. 1969). The most abundant morphotype is RONDEL. It is widespread in several subfamilies, but in temperate areas it characterizes the Pooideae, which produces it in large amount. The plants from that subfamily exhibit a C3 metabolism and mainly develop in temperate environments. Most of the old-world cereals belong to that subfamily. Even if they were less abundant, BILOBATE short cells were constantly present in variable amounts. They are common in the plants from the Panicoideae subfamily. These species are adapted to a warmer climate and often present a C4 metabolism. They spread over the intertropical areas, with some exceptions, in particular certain wild or cultivated millets which spread over temperate areas. Several C4 spontaneous panicoids (e.g. Bothriochloa ischaemum, Cenchrus incertus, Chrysopogon gryllus, Digitaria ischaemum, Echinochloa colona, E. crusgalli, Eriochloa villosa, Panicum dichotomiflorum, P. capillare, Setaria pumila, Sorghum halepense) are present on the territory of Romania, most of them being weeds (Ciocârlan 2000; Sârbu et al. 2001; Sîrbu and Oprea 2011; Table 3).

Some domesticated panicoids are also currently grown in Romania: Panicum miliaceum, Setaria italica, Sorghum bicolor, S. cernuum, S. dochna and S. sudanese (Table 3). Although the Panicoideae subfamily produces abundant BiLoBATE phytoliths, these forms can also occur in few festucoid grasses and some chloridoid grasses (Metcalfe 1960).

Phragmites sp. (a C3 plant of the grass subfamily Arundinoideae) may be responsible for the sporadic occurrence of SADDLE short cells phytoliths (Ollendorf et al. 1988), which may alternatively come from few species of the Chloridoideae subfamily, which is almost entirely distributed over tropical areas. In the inflorescences bracts (glumes, lemma and palea), these short-cell phytoliths are replaced by PAPILlATE (Delhon 2008).

Long cells gather epidermal cells (ELONGATE ENTIRE, E. DENDRITIC, E. SINUATE), hairs and other epidermal excrescences (ACUTE BULBOSUS). Bulliform cells, located in the leaves, along the nervures, provide BULLIFORM FLABELLATE and BLOCKY morphotypes. Among BULLIFORM FlABELlATE, the Phragmites-type was distinguished (see Gao et al. 2017; Li et al. 2014; Liu et al. 2013; Zhang et al. 2010).

The epidermal cells present morphological variations in vegetative parts (leaves and stems) and at inflorescences level (glumes, lemma and palea). Dendritic forms (Elongate DENDRITIC) are produced in the inflorescence bracts, while sinuous forms (ELONGATE SINUATE) are produced rather at the leaves level. Smooth shapes (ELONGATE ENTIRE) are more widespread, and they are the only ones represented in stems.

In some cases, silica skeletons could be observed. These multi-cells phytoliths correspond to silicified epidermal cells in connection (Rosen 1992). In all cases, they originated from grassy epidermis which are either from vegetative parts (ELONGATE ENTIRE morphotypes and short-cells) or from inflorescences bracts (ELONGATE DENDRITIC morphotypes and PAPILlATE). These forms are rarely observed in samples from natural (non-archaeological) contexts because of preservation (bioturbations) or statistical (low concentration) hazard. Their presence is often taken as an evidence of in situ accumulation and decomposition of plants or material of plant origin, in a context of low disturbance (in particular in pastoral sites, in the form of dung or bedding for the livestock: Cabanes et al. 2009; Portillo et al. 2014).

\section{Phytolith assemblages}

Generally, except for the sample Tol10.8, phytoliths derived from grasses dominate all the spectra (Fig. 5, Table 2). High representation of this family is explained by its very high phytolith production. Even so, only an anthropogenic accumulation of grasses in the analysed levels can explain the relative and absolute abundances of grassland phytoliths. In addition, we note a punctual presence of silica skeletons and a good representation of inflorescence bracts phytoliths (especially ELONGATE DENDRITIC forms). Furthermore, the presence of well-preserved elongate dendritic, at exceptionally high ratios, seems to indicate a very good preservation of phytoliths (cf. Cabanes et al. 2009, 2011). In natural contexts, the proportion of DENDRITIC phytoliths remains usually low (Novello and Barboni 2015), while it sometimes reaches higher values in archaeological context (Berlin et al. 2003; Portillo and Albert 2011). DenDRITIC phytolith abundance is often interpreted as an in situ presence of grass spikelets (Dal Corso et al. 2018; Danu et al. 2019; Delhon et al. 2008). All these observations contribute to suggest that most of the studied samples are derived from an important accumulation of various parts of grasses, which could be linked with human activities. 
Table 3 List of C4 Panicoideae species in Romania

\begin{tabular}{|c|c|c|c|c|}
\hline Panicoideae species & Indigenous* & Cultivated* & Adventive* & $\mathrm{C} 4 * *$ \\
\hline Bothriochloa ischaemum (L.) Keng & $\bullet$ & & & (a) \\
\hline Cenchrus incertus M. A. Curtis & & & $\bullet$ & (b) \\
\hline Chrysopogon gryllus (L.) Trin & $\bullet$ & & & (b) \\
\hline Digitaria ischaemum Schreb. ex Mühl. & $\bullet$ & & & (c) \\
\hline Digitaria sanguinalis (L.) Scop. & $\bullet$ & & & (b) \\
\hline Echinochloa colona (L.) Link & & & $\bullet$ & (b) \\
\hline Echinochloa crus-galli (L.) Beauv. & $\bullet$ & & & (b) \\
\hline Echinochloa frumentacea (Roxb.) Link & & & $\bullet$ & (d) \\
\hline Echinochloa oryzicola (Vasing.) Vasing. & & & $\bullet$ & (e) \\
\hline Echinochloa oryzoides (Ard.) Frisch & & & $\bullet$ & (f) \\
\hline Echinochloa phyllopogon (Stapf) Koss. & $\bullet$ & & & (g) \\
\hline Eriochloa villosa (Thunb.) Kunth & & & $\bullet$ & (h) \\
\hline Panicum capillare $\mathrm{L}$. & & & $\bullet$ & (b) \\
\hline Panicum dichotomiflorum Michx. & & & $\bullet$ & (b) \\
\hline Panicum miliaceum L. & & $\bullet$ & & (b) \\
\hline Paspalum paspalodes (Michx.) Scribner & & & $\bullet$ & (i) \\
\hline Panicum schinzii Hack. & & & $\bullet$ & (j) \\
\hline Setaria faberi J. Herrm & & & $\bullet$ & $(\mathrm{k})$ \\
\hline Setaria italica (L.) Beauv. & & $\bullet$ & & (b) \\
\hline Setaria pumila (Poir) Roem. et Schult. & $\bullet$ & & & (1) \\
\hline Setaria verticillata (L.) Beauv. & $\bullet$ & & & (c) \\
\hline Setaria viridis (L.) Beauv. & $\bullet$ & & & (c) \\
\hline Sorghum bicolor (L.) Moench & & $\bullet$ & & (c) \\
\hline Sorghum cernuum (Ard.) Host. & & $\bullet$ & & $(\mathrm{m})$ \\
\hline Sorghum dochna (Forssk.) Snowden & & $\bullet$ & & (n) \\
\hline Sorghum halepense (L.) Pers. & & & $\bullet$ & (c) \\
\hline Sorghum sudanese (Piper) Stapf & & $\bullet$ & & (c) \\
\hline Tripidium ravennae (L.) Scholz & & & $\bullet$ & (o) \\
\hline
\end{tabular}

*cf.: Ciocârlan 2000; Sârbu et al. 2001; Sîrbu and Oprea 2011

**References for C4 photosynthetic pathway: (a) Waller and Lewis 1979; (b) Downton 1975; (c) Rhagavendra and Das 1978; (d) Voznesenskaya et al. 2006; (e) Ueno and Takeda 1992; (f) Mitchell and Sheehy 2000; (g) Gibson et al. 1999; (h) Follak et al. 2020; (i) James et al. 2013; (j) Brown and Brown 1975; (k) Bazzaz 1996; (l) Tuba et al. 2003; (m) Mall 2019; (n) Erdei et al. 2009; (o) Shimomae et al. 2015)
Several samples (Tol08.8, 08.9, 08.11, 10.11, 10.13, 10.3, 10.5 and 10.2) are characterized by a low content (each circa. $2 \%$ ) of phytoliths possibly derived from dicots. Only two other samples contain very high amounts of SPHEROID from dicots (Tol10.8: 22.6\% and Tol10.14: 48.8\%). The wood from broadleaved trees and conifers, and therefore its ash, contains only few phytoliths (Delhon 2010), which seem to be mainly produced by the green parts (leaves, young branches). Based on low phytoliths production from dicots compared to that of grasses, relatively modest percentages of these morphotypes can be interpreted as meaningful. Low phytoliths production from dicotyledonous plants involves a specific accumulation of these plants in the levels of Tol10.8 and Tol10.14, which could be related to some aspects concerning the use of woody plants as fuel for salt production. Among short cells, RONDEL and CREnATE forms mainly produced by Pooideae are dominant, but we mention a very good representation of BilobAte (up to $25.8 \%$ ), especially at the top of diagram (starting from the Tol10.11 sample). It may suggest the presence of wild panicoids but also of cultivated millets. Concerning the spontaneous species from Panicoideae, we assume that the adventive ones (see Table 3 ) are less likely and therefore only a few spontaneous species could be involved in the phytolith record of Hălăbutoaia: Chrysopogon gryllus, Dichanthium ischaemum, Digitaria sanguinalis, Echinochloa crus-galli, Setaria pumila, S. verticillata and $S$. viridis. Regarding the domesticated millets, the study of plant macroremains confirms the presence of Panicum sp. and $P$. miliaceum in Neolithic sites on the Romanian territory (Cârciumaru et al. 2004; Comșa 1996) but also in CucuteniTrypillian sites from Moldavia (Janushevich 1976), Slovakia (where Setaria viridis was also mentioned) or Ukraine (Hunt 


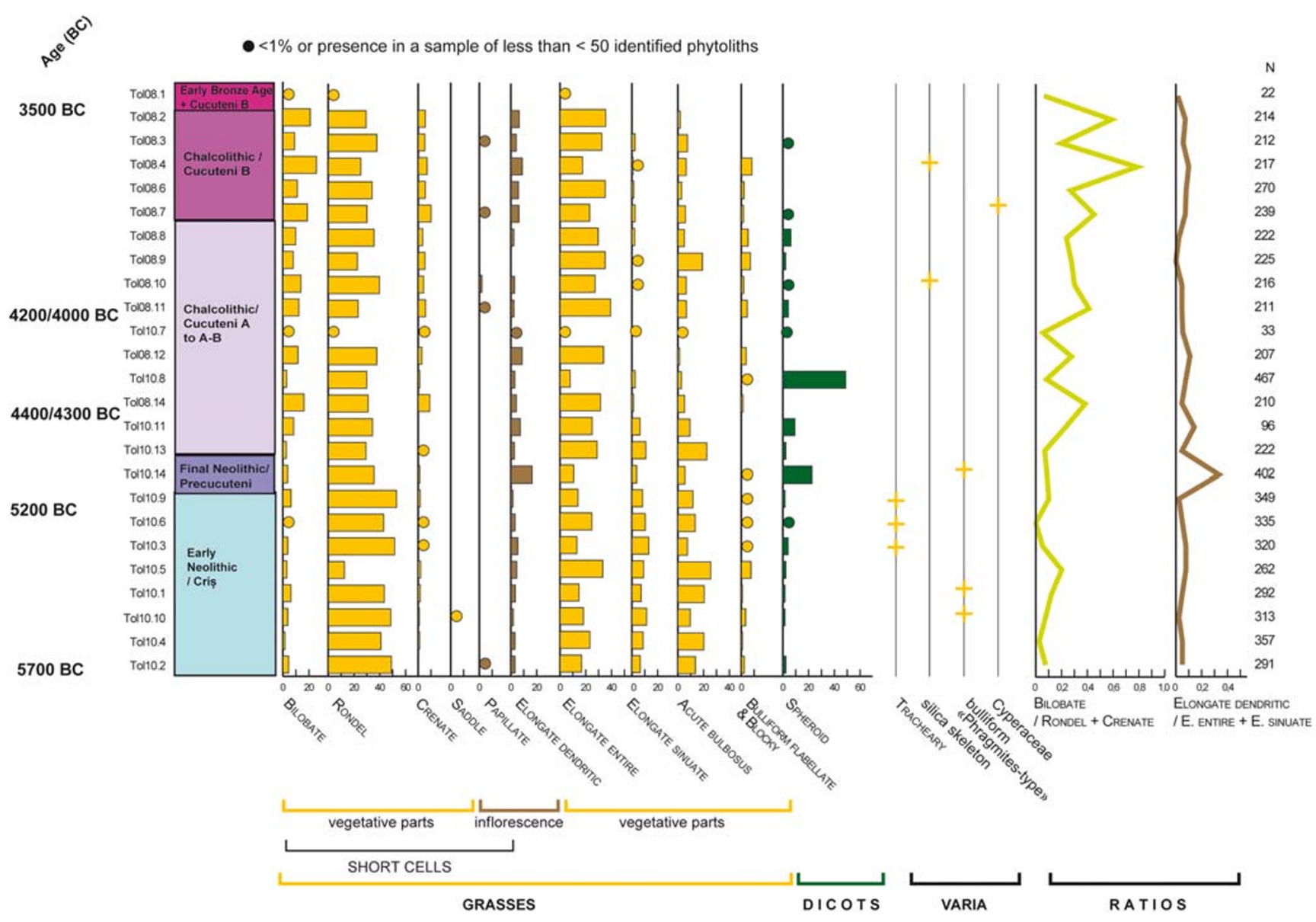

Fig. 5 Phytolith diagram from Hălăbutoaia - Țolici

et al. 2008). Morphotypes typical of panicoid grasses are also attested in other Romanian Cucutenian site from Neamț County, Răuceşti, but in lower amounts (11\% BiLOBATE in cultural layer, cf. Danu et al. 2016). At Hălăbutoaia - Țolici, BILOBATE showed varied forms. Beside the so-called "dumbbell" form (Madella et al. 2005), very elongated morphotypes were observed with bulging extremities connected through a long and thin axis (these forms are often fragmented, broken in the form of half-dumbbells). Also, much more contracted forms, almost square-shaped with a less evidenced central constriction, were noticed. Many intermediate forms also occurred. The identification of millet phytolith has been questionable over time. Some studies showed that there is no valid method for separating Setaria italica and Panicum miliaceum based on inflorescence phytolith analysis (Harvey and Fuller 2005; Parry and Hodson 1982), but new characters of phytolith identification for husks and leaves of these two species have been developed and evaluated as a reliable way of distinguishing foxtail millet from common millet ( $\mathrm{Lu}$ et al. 2009; Out and Madella 2016). The possibility of distinguishing panicoid grasses in a fossil phytolith assemblage has been shown in the records of grass short-cell phytoliths (Bilobate, Polylobate and Cross) and silica skeletons from sediments of a Bronze Age settlement situated in northern Italy (Dal Corso et al. 2017). Numerous cut silica skeletons, from grass culms or culms and from grass inflorescences, are derived from panicoid, but also pooid were present in phytolith record, indicating crop processing activities near the site of Fondo Paviani (Italy).

Therefore, several species are probably involved in the abundance of BILOBATE at Hălăbutoaia site, but the absence of local references samples from plants prevented further identification. More research should be carried out in the future on local wild and cultivated Panicoideae.

\section{Phytolith ratios}

It must be noted that the combustion process leaves no easily visible and unequivocal tracks on phytoliths (Parr 2006; Evett and Cuthrell 2017), despite some changes in their refractive index whose observation remains technically difficult (Elbaum et al. 2003). According to Cabanes and ShahackGross (2015), pitting and melting become common after the combustion. We did not notice such traces, but considering the archaeological context (large amount of ash and charcoal, cf. Dufraisse 2011; Sordoillet et al. 2018), it is very likely that 
these microscopic remains come mainly from plant used as fuel or at least were related to fire purposes. To go further in the interpretation of the phytoliths spectra, we used two ratios developed in order to give a better illustration of the relative variations between selected morphotypes. The ratio of Bilobate vs. Rondel and CRenATE (BIL/RON + CRE) is a proxy for the contribution of panicoid grasses vs. pooid grasses in the phytolith record, and the ratio of ELONGATE DENDRITIC vs. ElONGATE ENTIRE and SinUate (ELO DEN/ ELO_ENT + ELO_SIN) quantifies the proportion of phytoliths from inflorescences bracts vs. phytoliths from vegetative parts.

The BIL/RON + CRE ratio is a simplification of Ic index ("climatic Index", in which SADDLES also contribute to the divisor) used in tropical regions as a climatic indicator (Twiss 1987, 1992). It draws the proportion of C3 (temperate) grasses against $\mathrm{C} 4$ (thermophilic) grasses. It is used here in an unusual way, since variations of the abundance of the forms that characterize the Panicoideae appear to be more related to the selection of certain spontaneous grasses (e.g. wild millets) or cultivated panicoid taxa (cultivated millet) rather than to variations in their abundance in the natural grasslands around the site.

The ELO_DEN/ELO_ENT+ELO_SIN ratio varies either according to season of harvest (presence or absence of spikelets) or to the plant parts selected. The use of straws, of the whole plant, or of residues from spikelets processing can thus be traced. According to Regev et al. (2015), a ratio of leafstem to inflorescence which is lower than 1 indicates a tendency toward having more inflorescence (chaff), and a ratio lower than 0.5 indicates predominance of inflorescence phytoliths (most probably an intentional selection of chaff). A ratio higher than 1 indicates a tendency toward having more leaves and stems (e.g. straw, hay), and a ratio above 1.5 indicates predominance of leaves/stems (e.g. straw, hay). Phytolith assemblages from Hălăbutoaia - Țolici site show that the ratio ELO_DEN/ELO_ENT + ELO_SIN is lower than 0.5 ; thus, we assume that may indicate the intentional use of chaff as fuel. Moreover, this ratio may also indicate if wild grasses or cereals are preferentially used. High amounts of grass inflorescence bracts phytoliths are often considered more likely related to cultivated grasses than to spontaneous ones, due to the facts that grains produce bigger spikelets and are normally harvested during seasons when inflorescences are fully developed.

The BIL/RON + CRE ratio shows a curve made of two steps. The first one corresponds to low values (nearly always $<0.2$ ) and stretches from the bottom of the sequence to Tol10.11 sample. The second one corresponds to the increase of the index (nearly always $>0.2$ and reaching 0.6 in Tol08.4) in the upper part of the sequence. Thus, the use of panicoid grasses remains as fuel seems to increase in the second part of the sequence. Considering the recurrence of high proportion of grass inflorescences bracts phytoliths, the recourse to cultivated grasses (or their by-products) seems highly possible. These two observations argue for an agricultural origin of the Panicoideae grasses involved in the record and thus to an increase of the use of their by-products as fuel in the second part of the sequence. Despite they may enhance the main traits perceived through the phytolith diagram, these indices remain complex and their variations potentially linked to several different anthropic or natural phenomena. It is not so simple to decipher all the information they contain; in that purpose, we finally correlated them with data obtained from other domains.

\section{Correlations with other achaeobotanical data}

Palynological analysis of a sediment core taken in a swamp nearby the salt spring and the archaeological site (Danu et al. 2010) made it possible to highlight, during the Cucutenian period, a relatively open vegetation, marked by presence of anthropogenic activities: agriculture, animal farming and salt exploitation. This pollen record (cf. Danu et al. 2010) is dominated by non-arboreal pollen, such as Poaceae (up to 40\%) and from herbaceous plants from grassland pasture (Cichorioideae, Anthemideae, Apiaceae, etc.). Within this open environment appear numerous anthropogenic indicators: pollen grains of Cerealia, pollen of weeds (Polygonum aviculare) and plants of trampled and grazed areas (Plantaginaceae, Rumex). Among the non-pollen palynomorphs, coprophilous fungi (Sordariaceae, HdV 55) have been identified suggesting a pastoral presence nearby the site. In this open plant landscape, anthracological data (Dufraisse 2011) highlights opportunistic exploitation, apparently without any selection of particular woody species, of formations such as riverine forests and mixed oak forests as wood fuel supplies. Symmetrically, phytoliths analysis could complete the range of the opportunistic harvest of fuel by also considering the available non-wood materials. The use of Poales herbs as fuel (and maybe for temperature control) is also presumed in other fire-related contexts (Esteban et al. 2018). The high representation of grass phytoliths at Hălăbutoaia and their, at least partly, agricultural origin reveals that herbaceous plants have been used as fuel or at least had a potentially important role in operational salt exploitation chain.

Moreover, it appears that this material is not subject to strong selection as various species from various subfamilies are involved and as it could, at a certain extent, be derived from agricultural by-products.

Although the analysis of non-pollen palynomorphs indicated the animal presence in the past landscape of Hălăbutoaia Tolici site (Danu et al. 2010), the presumption of using animal dung as fuel cannot be taken into account because dung has not been observed either macroscopically during the field 
excavation or microscopically in the micromorphological analyses (Sordoillet et al. 2018). Furthermore, compared to plant resources (wood and/or grasses), dung is a bad fuel that, in addition, introduces into the ash more phosphates and nitrogen, which is probably not required if it gets mixed with salt.

This complementarity between agro-pastoral systems and salt extraction activities is supported by results of palynological analysis (Danu et al. 2010) which highlight the presence of agro-pastoral markers (anthropogenic pollen indicators and non-pollen palynomorphs like coprophilous fungal spores which strongly suggest the pastoral/breeding activity), as well as the presence of forest exploitation indicators (deforestation, erosion) in close connection with salt exploitation.

\section{Conclusion}

The phytoliths analysis from Hălăbutoaia - Țolici saltwater spring made it possible to highlight assemblages with anthropogenic origin in which grasses have a major role, excepting few cases in which dicots are well represented. Phytoliths mostly derived from the subfamily Panicoideae are well represented. Their absolute abundance tends to increase along the sequence, to detriment of those massively produced by plants from the Pooideae subfamily. Given the high sedimentation rate, this increase cannot be due to pollution caused by current vegetation. The abundance of BILOBATE phytoliths and glumes phytoliths emphasizes the possible involvement of cultivated Panicoideae, but more evidences are needed to draw a definitive conclusion. Plant phytoliths were introduced into the site via anthropogenic input, but microscopic observation of phytoliths does not allow the determination of the purpose in which plants were brought. Despite the fact that it is not possible to determine whether phytoliths are burnt or not (burned phytoliths have the same aspect as those that are not burned) their abundance in an archaeological context marked by fire-related activities makes it very likely that their presence may be related to fire purpose. It is thus very possible that grasses have played a role in the salt-making pyrotechnology, whether for ignition, combustion or temperature control.

Acknowledgements This research was partly founded by the Commission for Foreign Excavations (French Ministry of Foreign Affairs) and the National Centre of Scientific Research (CNRS, UMR 8215 Trajectoires). Special thanks to the History \& Archaeology Museum of Piatra Neamt for their continued cooperation. This work was done also within the project "Development of innovation capacity and increasing the impact of excellence research at UAIC". This project is funded by the Ministry of Research and Innovation within Program 1 - Development of the national RD system, Subprogram 1.2 - Institutional Performance RDI excellence funding projects, Contract no.34PFE/19.10.2018.

Funding Open Access is funded by the Ministry of Research and Innovation within Program 1 - Development of the national RD system,
Subprogram 1.2 - Institutional Performance - RDI excellence funding projects, Contract no.34PFE/19.10.2018.

Open Access This article is licensed under a Creative Commons Attribution 4.0 International License, which permits use, sharing, adaptation, distribution and reproduction in any medium or format, as long as you give appropriate credit to the original author(s) and the source, provide a link to the Creative Commons licence, and indicate if changes were made. The images or other third party material in this article are included in the article's Creative Commons licence, unless indicated otherwise in a credit line to the material. If material is not included in the article's Creative Commons licence and your intended use is not permitted by statutory regulation or exceeds the permitted use, you will need to obtain permission directly from the copyright holder. To view a copy of this licence, visit http://creativecommons.org/licenses/by/4.0/.

\section{References}

Albert RM, Lavi O, Estroff L, Weiner S, Tsatskin A, Ronen A, LevYadun S (1999) Mode of occupation of Tabun cave, Mt Carmel, Israel during the Mousterian period: a study of the sediments and phytoliths. J Archaeol Sci 26(10):1249-1260. https://doi.org/10. 1006/jasc. 1999.0355

Alexandre A, Meunier JD, Lézine AM, Vincens A, Schwartz D (1997) Phytoliths: indicators of grassland dynamics during the late Holocene in intertropical Africa. Palaeogeogr Palaeoclimatol Palaeoecol 136:213-229. https://doi.org/10.1016/S0031-0182(97) 00089-8

Alexianu M, Dumitroaia G, Monah D (1992) Exploatarea surselor de apă sărată din Moldova: o abordare etnoarheologică. Thraco-Dacica 13(1-2):159-167

Alexianu M, Weller O, Brigand R (2007) Izvoarele de apă sărată din Moldova Subcarpatică. Cercetări etnoarheologice. Casa Editorială Demiurg Plus, Iaşi

An X, Lu H, Chu G (2015) Surface soil phytoliths as vegetation and altitude indicators: a study from the southern Himalaya. Sci Rep 5: 15523. https://doi.org/10.1038/srep15523

Bazzaz FA (1996) Linking physiological, population, and community ecology. Cambridge University Press, New York

Berlin A, Ball TB, Thompson R, Kittleson D, Herbert SC (2003) Ptolemaic Agriculture, "Syrian Wheat", and Triticum aestivum. J Archaeol Sci 30(1):115-121. https://doi.org/10.1006/jasc.2002. 0812

Borba-Roschel M, Alexandre A, Drummond Chicarino Varajão AF et al (2006) Phytoliths as indicators of pedogenesis and paleoenvironmental changes in the Brazilian cerrado. J Geochem Explor 88(1-3):172-176. https://doi.org/10.1016/j.gexplo.2005.08. 032

Bozarth S (1992) Classification of opal phytoliths formed in selected Dicotyledons native to the Great Plains. In: Rapp G, Mulholland S (eds) Phytoliths systematics, emerging issues. Plenum Press, New York, pp 193-214

Brigand R, Weller O (2013) Neolithic and chalcolithic settlement patterns in Central Moldavia (Romania). Documenta Praehistorica 40:195207. https://doi.org/10.4312/dp.40.15

Brigand R, Weller O (2018) Neo-Eneolithic settlement pattern and salt exploitation in Romanian Moldavia. J Archaeol Sci: Reports 17:68 78. https://doi.org/10.1016/j.jasrep.2017.10.032

Brown RH, Brown WV (1975) Photosynthetic characteristics of Panicum milioides, a species with reduced photorespiration. Crop Sci 15: 681-685

Cabanes D, Shahack-Gross R (2015) Understanding fossil phytolith preservation: the role of partial dissolution in paleoecology and 
archaeology. PLoS One 10(5):e0125532. https://doi.org/10.1371/ journal.pone. 0125532

Cabanes D, Burjachs F, Expósito I, Rodríguez A, Allué E, Euba I, Vergès JM (2009) Formation processes through archaeobotanical remains: the case of the Bronze Age levels in El Mirador cave, Sierra de Atapuerca, Spain. Quat Int 193:160-173. https://doi.org/10.1016/j. quaint.2007.08.002

Cabanes D, Weiner S, Shahack-Gross R (2011) Stability of phytoliths in the archaeological record: a dissolution study of modern and fossil phytoliths. J Archaeol Sci 38:2480-2490

Cârciumaru M, Pleșa M, Mărgărit M (2004) Omul și plantele. Manual de analiză carpologică. Editura Cetatea de Scaun, Târgoviște

Carter JA, Lian OB (2000) Palaeoenvironmental reconstruction from the last interglacial using phytolith analysis, southeastern North Island, New Zealand. J Quat Sci 15(7):733-743. https://doi.org/10.1002/ 1099-1417(200010)15:7<733::AID-JQS532>3.0.CO;2-J

Ciocârlan V (2000) Flora ilustrată a României, Pteridophyta et Spermatophyta. Editura Ceres, București

Comșa E (1996) Viața oamenilor din spațiul Carpato-Danubiana-Pontic în mileniile 7-4 î hr (the life of people in the Carpatho-DanubianPontic region in the 7 th- 4 th millennia b.c., in Romanian). Editura didactică şi pedagogică, Bucureşti

Currie HA, Perry CC (2007) Silica in plants: biological, biochemical and chemical studies. Ann Bot 100:1383-1389

Dal Corso M, Nicosia C, Balista C, Cupitò M, Dalla Longa E, Leonardi G, Kirleis W (2017) Bronze age crop processing evidence in the phytolith assemblages from the ditch and fen around Fondo Paviani, northern Italy. Veget Hist Archaeobot 26:5-24

Dal Corso M, Out WA, Ohlrau R, Hofmann R, Dreibrodt S, Videiko M, Müller J, Kirleis W (2018) Where are the cereals? Contribution of phytolith analysis to the study of subsistence economy at the Trypillia site Maidanetske (ca. 3900-3650 BCE), Central Ukraine. J Arid Environ 157:137-148. https://doi.org/10.1016/j.jaridenv. 2018.06.009

Danu M, Gauthier E, Weller O (2010) Human impact and vegetation history on salt spring exploitation (Hălăbutoaia-T,olici, Petricani, Neamt, Romania). International Journal of Conservation Sciences 1(3):167-173

Danu M, Diaconu V, Bejenaru L (2016) Chalcolithic agropastoralism traces in the site of Răucești (Neamț County, Romania): phytoliths and animal remains. International Journal of Conservation Sciences 7(4):1071-1080

Danu M, Messager E, Carozza JM, Carozza L, Bouby L, Philibert S, Anderson P, Burens A, Micu C (2019) Phytolith evidence of cereal processing in the Danube Delta during the chalcolithic period. Quat Int 504:128-138. https://doi.org/10.1016/j.quaint.2018.03.033

Delhon C (2008) Potentiel de l'analyse des phytolithes contenus dans les pâtes céramiques et les matériaux de construction. Dégraissants organiques: identifications, nomenclatures et référentiels, S.n. Cahiers des thèmes transversaux ArScAn 7, 2005-2006: 86-93

Delhon C (2010) Phytolithes et taphonomie, apport de l'expérimentation à la quantification des phytolithes dans les cendres de bois. Palethnologie 2:95-107

Delhon C, Alexandre A, Berger JF, Thiébault S, Brochier JL, Meunier JD (2003) Phytolith assemblages as a promising tool for reconstructing Mediterranean Holocene vegetation. Quat Res 59:48-60. https://doi. org/10.1016/S0033-5894(02)00013-3

Delhon C, Martin L, Argant J, Thiébault S (2008) Shepherds and plants in the Alps: multi-proxy archaeobotanical analysis of neolithic dung from "La Grande Rivoire" (Isère, France). J Archaeol Sci 35(11): 2937-2952. https://doi.org/10.1016/j.jas.2008.06.007

Downton WJS (1975) The occurrence of C4 photosynthesis among plants. Photosynthetica 9:96-105

Dufraisse A (2011) Analyse anthracologique du site de Hălăbutoaia à Tolici: bilan des etudes 2007-2011. In Weller O, Exploitations pré et protohistoriques des sources salées de Moldavie : le cas de Țolici (dép. Neamț, Roumanie) 2011 - 4e année : Bilan des études du site de Țolici, prospections et analyses spatiales en Moldavie souscarpatique (2008-2011). Rapport MAE: 35-48. Unpublished

Dufraisse A, Sordoillet D, Weller O (2010) The alteration of Neolithic wood charcoal from the salt spring of Poiana Slatinei in Lunca (Neamţ, Romania): a natural evolution or consequence of exploitation techniques?. In: Théry-Parisot I, Chabal L, Costamagno S (eds) Taphonomy of burned organic residues and combustion features in archaeological contexts. Palethnologie 2, 117-127. http://blogs. univ-tlse2.fr/palethnologie/en/2010-10-dufraisse-et-alii/

Dumitroaia G (1994) Depunerile Neo-Eneolitice de la Lunca și Oglinzi, județul Neamț. Memoria Antiquitatis 19:7-82

Dumitroaia Gh, Munteanu R, Weller O et al (2008) Un nou punct de exploatare a sării în preistorie: Țolici-Hălăbutoaia, jud. Neamț, In: Monah D, Dumitroaia Gh, Garvăn D (eds), Sarea. De la prezent la trecut. Editura C. Mătasă, coll. Bibliotheca Memoriae Antiquitatis 20, Piatra Neamt, pp 203-224

Elbaum R, Weiner S, Albert RM, Elbaum M (2003) Detection of burning of plant materials in the archaeological record by changes in the refractive indices of siliceous Phytoliths. J Archaeol Sci 30:217-226

Erdei E, Pepo P, Boros N, Toth S, Szabo B (2009) Morphological and biochemical indicators of drought tolerance in sweet sorghum (Sorghum dochna L.). Cereal Res Commun 37:157-160

Esteban I, Marean CW, Fisher EC, Karkanas P, Cabanes D, Albert RM (2018) Phytoliths as an indicator of early modern humans plant gathering strategies, fire fuel and site occupation intensity during the Middle Stone Age at pinnacle point 5-6 (south coast, South Africa). PLoS One 13(6):e0198558. https://doi.org/10.1371/ journal.pone.0198558

Evett RR, Cuthrell RQ (2017) Testing phytolith analysis approaches to estimate the prehistoric anthropogenic burning regime on the Central California coast. Quat Int 434:78-90

Follak S, Schwarz M, Essl F (2020) First record of Eriochloa villosa (Thunb.) Kunth in Austria and notes on its distribution and agricultural impact in Central Europe. BioInvasions Records 9(1):8-16. https://doi.org/10.3391/bir.2020.9.1.02

Fredlund G, Tieszen L (1997) Calibrating grass phytolith in climatic terms: application to late Pleistocene assemblages from Kansas and Nebraska. Palaeogeogr Palaeoclimatol Palaeoecol 136(1-4): 199-211

Gao G, Jie D, Wang Y, Liu L, Liu H, Li D, Li N, Shi J, Leng C (2017) Phytolith reference study for identifying vegetation changes in the forest grassland region of Northeast China. Boreas 47(2):2-17. https://doi.org/10.1111/bor.12280

Garnier A, Neumann K, Eichhorn B, Lespez L (2012) Phytolith taphonomy in the middle- to late-Holocene fluvial sediments of Ounjougou (Mali, West Africa). The Holocene 23:416-431. https://doi.org/10. $1177 / 0959683612463102$

Gibson KD, Foin TC, Hill JE (1999) The relative importance of root and shoot competition between water-seeded rice and Echinochloa phyllopogon. Weed Res 39:181-190. https://doi.org/10.1046/j. 1365-3180.1999.00135.x

Harvey EL, Fuller DQ (2005) Investigating crop processing using phytolith analysis: the example of rice and millets. J Archaeol Sci 32: 739-752

Hunt HV, Vander Linden M, Liu X et al (2008) Millets across Eurasia: chronology and context of early records of the genera Panicum and Setaria from archaeological sites in the Old World. Veg Hist Archaeobotany 17(sup. 1):S5-S18. https://doi.org/10.1007/ s00334-008-0187-1

ICPT: Neumann K, Albert RM, Ball T et al. (2019) International code for phytolith nomenclature (ICPN) 2.0. Ann Bot 124(2):189-199. https://doi.org/10.1093/aob/mcz064

James TK, Rahman A, Dowsett C, Trolove M (2013) Fenoxaprop for control of yellow bristle grass in pasture and its efficacy on other $\mathrm{C} 4$ 
grasses. New Zealand Plant Protection 66:118-123. https://doi.org/ 10.30843/nzpp.2013.66.5718

Janushevich ZV (1976) Cultivated plants in south-western USSR according to paleobotanical investigation. Editura Ştiinţa, Chişinău

Lebreton V, Thery-Parisot I, Bouby L et al (2017) Archéobotanique et taphonomie. In: Brugal JP (dir.) Taphonomie S, Editions des archives contemporaines, collection Sciences archéologiques. Paris, pp 291-328

Li N, Jie D, Yong G et al (2014) Response of phytoliths in Phragmites communis to elevated $\mathrm{CO} 2$ concentration in Songnen grassland, China. Quat Int 321:97-104. https://doi.org/10.1016/j.quaint.2013. 10.007

Li D, Jie D, Wang Y, Liu L, Liu H, Gao G, Gao Z, Li N, Shi J (2017) Holocene climate reconstruction based on herbaceous phytolith indices from an AMS C-dated peat profile in the Changbai Mountains, Northeast China. Quat Int 447:144-157. https://doi.org/10.1016/j. quaint.2017.01.015

Liu LD, Jie DM, Liu HY et al (2013) Change characters of Phragmites australis phytolith in Northeast China. Chinese J Plant Ecol 37(9): 861-871. https://doi.org/10.3724/SP.J.1258.2013.00090

Lu HY, Wu NQ, Liu KB et al (2007) Phytoliths as quantitative indicators for the reconstruction of past environmental conditions in China II: palaeoenvironmental reconstruction in the loess plateau. Quaternary Science Review 26(5-6):759-772. https://doi.org/10.1016/j. quascirev.2006.10.006

Lu H, Zhang J, Wu N, Liu K, Xu D, Li Q (2009) Phytoliths analysis for the discrimination of foxtail millet (Setaria italica) and common millet (Panicum miliaceum). PLoS One 4(2):e4448. https://doi.org/ 10.1371/journal.pone.0004448

Madella M, Lancelotti C (2012) Taphonomy and phytoliths: a user manual. Quat Int 275:76-83. https://doi.org/10.1016/j.quaint.2011.09. 008

Madella M, Alexandre A, Ball T (2005) International code for phytolith nomenclature 1.0. Ann Bot 96(2):253-260. https://doi.org/10.1093/ aob/mci172

Mall TP (2019) Ethno-veterinary potential of underutilised millets from Bahraich: an overview. Journal of Medical Research and Health Sciences 2(10):743-783. https://doi.org/10.15520/jmrhs.v2i10.126

Marinescu-Bîlcu S, Cârciumaru M, Muraru A (1981) Contributions to the ecology of pre- and proto-historic habitations at Tîrpesti. Dacia 25: $7-31$

Messager E, Lebreton V, Marquer L, Russo-Ermolli E, Orain R, RenaultMiskovsky J, Lordkipanidze D, Despriée J, Peretto C, Arzarello M (2011) Palaeoenvironments of early hominins in temperate and Mediterranean Eurasia: new palaeobotanical data from Palaeolithic key-sites and synchronous natural sequences. Quat Sci Rev 30: 1439-1447. https://doi.org/10.1016/j.quascirev.2010.09.008

Metcalfe CR (1960) Anatomy of monocotyledons. I. Gramineae. Clarendon Press, Oxford

Mitchell PL, Sheehy JE (2000) Genetic modification and agriculture. In: Sheehy JE, Mitchell PL, Hardy B (eds) Redesigning rice photosynthesis to increase yield. Proceedings of the Workshop on The Quest to Reduce Hunger: Redesigning Rice Photosynthesis, 30 Nov.-3 Dec. 1999, Los Bafios, Philippines. Makati City (Philippines): International Rice Research Institute and (The Netherlands), Elsevier Science BV, Amsterdam, pp 257-268

Monah D (2008) Arheologia preistorică a sării în România. Scurt istoric. In: Monah D, Dumitroaia Gh, Garvăn D (eds) Sarea, de la prezent la trecut, Bibliotheca Memoriae Antiquitatis, XX, Editura „Constantin Matasă”, Piatra-Neamț, pp 13-39

Murungi ML, McGlynn G, Lejju JB (2017) Alpine grassland palaeoecology of the Virunga volcanoes, East Africa: a new phytolith record from Mt. Muhavura. Quaternary International 434(B):102-116. https://doi.org/10.1016/j.quaint.2016.01.015
Novello A, Barboni D (2015) Grass inflorescence phytoliths of useful species and wild cereals from sub-Saharan Africa. J Archaeol Sci 59:10-22. https://doi.org/10.1016/j.jas.2015.03.031

Ollendorf AL, Mulholland SC, Rapp G (1988) Phytolith Analysis as a Means of Plant Identification: Arundo donax and Phragmites communis. Ann Bot 61(2):209-214 https://www.jstor.org/stable/ 42770279

Ollendorf AL (1988) Archaeological implications of a phytolith study at Tel Miqne (Ekron), Israel. Ann Bot 61:209-214. https://doi.org/10. 1179/jfa.1987.14.4.453

Out WA, Madella M (2016) Morphometric distinction between bilobate phytoliths from Panicum miliaceum and Setaria italica leaves. Archaeol Anthropol Sci 8:505-521

Parr JF (2006) Effect of fire on phytolith coloration. Geoarchaeology 21: $171-185$

Parry DW, Hodson MJ (1982) Silica distribution in the caryopsis and inflorescences bracts of foxtail millet ( Setaria italica (L.) Beauv.) and its possible significance in carcinogenesis. Ann Bot 49:531-540

Piperno DR (1988) Phytolith analysis: an archaeological and geological perspective. Academic, San Diego

Piperno DR (1989) The occurrence of phytoliths in the reproductive structures of selected tropical angiosperms and their significance in tropical paleoecology, paleoethnobotany, and systematics. Rev Palaeobot Palynol 61:147-173. https://doi.org/10.1016/00346667(89)90067-5

Piperno DR (2001) Phytoliths. In: Smol JP, JJB B, Last WM et al (eds) Tracking environmental change using lake sediments, volume 3: terrestrial, algal, and siliceous indicators. Kluwer Academic Publishers, Dordrecht, pp 235-251

Piperno DR (2006) Phytoliths: a comprehensive guide for archaeologists and paleoecologists. Alta Mira Press, Lanham. https://doi.org/10. 1017/S0016756807003159

Portillo M, Albert RM (2011) Husbandry practices and livestock dung at the Numidian site of Althiburos (El Médéina, kef governorate, northern Tunisia): the Phytolith and Spherulite evidence. J Archaeol Sci 38(12):3224-3233. https://doi.org/10.1016/j.jas. 2011.06.027

Portillo M, Kadowaki S, Nishiaki Y, Albert MA (2014) Early Neolithic household behavior at tell Seker al-Aheimar (upper Khabur, Syria): a comparison to ethnoarchaeological study of phytoliths and dung spherulites. J Archaeol Sci 42:107-118. https://doi.org/10.1016/j. jas.2013.10.038

Regev L, Cabanes D, Homsher R, Kleiman A, Weiner S, Finkelstein I, Shahack-Gross R (2015) Geoarchaeological investigation in a domestic Iron Age quarter, Tel Megiddo, Israel. Bull Am Sch Orient Res 374:135-157. https://doi.org/10.5615/bullamerschoorie.374. 0135

Rhagavendra AS, Das VSR (1978) The occurrence of C4 photosynthesis: a supplementary list of C4 plants reported during late 1974-mid1977. Photosynthetica 12:200-208

Rosen AM (1992) Preliminary identification of silica skeletons from near eastern archaeological sites: an anatomical approach. In: Rapp G, Mulholland SC (eds) Phytolith systematics. Advances in archaeological and museum science, vol 1. Springer, Boston, pp 129-147. https://doi.org/10.1007/978-1-4899-1155-1_7

Rovner I (1971) Potential of opal phytoliths for use in paleoecological reconstruction. Quat Res 1(3):343-359. https://doi.org/10.1016/ 0033-5894(71)90070-6

Runge F (1999) The opal phytolith inventory of soils in Central Africa quantities, shapes, classification and spectra. Rev Palaeobot Palynol 107:23-53. https://doi.org/10.1016/S0034-6667(99)00018-4

Sârbu I, Ștefan N, Ivănescu L, Mânzu C (2001) Flora ilustrată a plantelor vasculare din estul României, II. Editura Universității Alexandru Ioan Cuza Iași

Shimomae K, Makabe S, Boriboonkaset T, Chin DP, Igawa T, Khan RS, Mii M, Nakamura I (2015) Enhanced efficiency of agrobacterium- 
mediated transformation by sulfamethazine treatment in ravenna grass, Erianthus ravennae (L.) Beauv. Global Advanced. Res J Agric Sci 4(11):761-768

Sîrbu C, Oprea A (2011) Plante adventive în flora României. Editura Ion Ionescu de la Brad, Iași

Sordoillet D, Weller O, Rouge N, Buatier M, Sizun JP (2018) Earliest salt working in the world: from excavation to microscopy at the prehistoric sites of Țolici and Lunca (Romania). J Archaeol Sci 89:46-55. https://doi.org/10.1016/j.jas.2017.11.003

Tuba Z, Raschi A, Lanini GM, Nagy Z, Helyes L, Vodnik D, Sanita di Toppi L (2003) Plant response to elevated carbon dioxide. In: Sanità di Toppi L, Pawlik-Skowronska B (eds) Abiotic stresses in plants. Publisher Springer, Dordrecht, pp 157-204. https://doi.org/10.1007/ 978-94-017-0255-3

Twiss PC (1987) Grass-opal phytoliths as climatic indicators of the Great Plains Pleistocene. In: Johnson WC (ed) Quaternary environments of Kansas. Guidebook series 5. Kansas Geological Survey, Lawrence, pp 179-188

Twiss PC (1992) Predicted world distribution of $\mathrm{C}_{3}$ and $\mathrm{C}_{4}$ grass phytoliths. In: Rapp G, Mulholland S (eds) Phytolith systematics emerging issues. Plenum Press, New York, pp 113-128

Twiss PC, Suess E, Smith RM (1969) Morphological classification of grass phytoliths. Soil Sci Soc Am J 33(1):109-115. https://doi.org/ 10.2136/sssaj1969.03615995003300010030x

Ueno O, Takeda T (1992) Photosynthesis pathways, ecological characteristics, and the geographical distribution of the Cyperaceae in Japan. Oecologia 89:195-203. https://doi.org/10.1007/BF00317218

Voznesenskaya EV, Franceschi VR, Chuong SDX, Edwards GE (2006) Functional characterization of phosphoenolpyruvate carboxykinasetype C4 leaf anatomy: immuno, cytochemical and ultrastructural analyses. Ann Bot 98:77-91. https://doi.org/10.1093/aob/mcl096

Waller SS, Lewis JK (1979) Occurrence of C3 and C4 photosynthetic pathways in North American grasses. J Range Manag 32(1):12-28
Weller O (2015) Neolithic and chalcolithic settlement patterns in Central Moldavia (Romania). Documenta Praehistorica 42:185-196. https:// doi.org/10.4312/dp.42.12

Weller O, Brigand R (2017) Recherches systématiques autour des sources salées de Moldavie. Bilan 2011-2013 et synthèse de 10 ans de prospections. Memoria Antiquitatis (2016) 31-32:163-270

Weller O, Dumitroaia Gh (2005) The earliest salt production in the world: an early Neolithic exploitation in Poiana Slatinei-Lunca, Romania. Antiquity 79 (306). http://www.antiquity.ac.uk/projgall/weller/

Weller O, Brigand R, Alexianu M (2007) Cercetări sistematice asupra izvoarelor de apă sărată din Moldova. Bilanţul exploatărilor din anii 2004-2007 efectuate în special în judetul Neamț. Memoria Antiquitatis 24:121-190

Weller O, Dumitroaia G, Sordoillet D et al (2008) Première exploitation de sel en Europe. Techniques et gestion de l'exploitation de la source salée de Poiana Slatinei à Lunca (Neamt, Roumanie). In: Weller O, Dufraisse A, Pétrequin P (eds) Sel, eau et forêt. D'hier à aujourd'hui. Actes de colloque international (Arc-et-Senans, 2006). Cahiers de la MSH Nicolas Ledoux 12 (Homme et Environnement 1). Presses Universitaires Franche-Comté, Besançon, pp 205-230

Weller O, Brigand R, Dumitroaia G et al (2015) A pinch of salt in the prehistoric eastern Carpathians mountains (Ro.). In: Alexianu M, Curcă RG, Cotiugă V (eds) Salt effect. From the ethnoarchaeology to the anthropology of salt. BAR international series 2760 . Archaeopress, Oxford, pp 125-133

Zhang J, Lu H, Wu N et al (2010) Phytolith evidence for rice cultivation and spread in mid-late Neolithic archaeological sites in central North China. Boreas 39:592-602. https://doi.org/10.1111/j.1502-3885. 2010.00145.x

Publisher's note Springer Nature remains neutral with regard to jurisdictional claims in published maps and institutional affiliations. 